\title{
Innovative offices for smarter cities, including energy use and energy-related carbon dioxide emissions
}

\author{
Yoram Krozer
}

\begin{abstract}
Background: Concentration of knowledge work in cities generates innovations entailing economic development. This paper addresses the challenge of turning around the present trend of urban sprawl toward the concentrated knowledge work in cities. The assumption is that dislocation of office and residential housing entailing longer commuting mileage is the main cause of urban sprawl.

Methods: The life cycle costs method is used for comparison of office systems. The present offices system is compared to the concentrated mega offices system outside cities, as well as the local and home offices within cities. The life cycle costs are assessed with statistical data on space, materials and energy, and information services. These are the main resources of the offices systems given labor and capital.

Results: Commuting costs about $22 \%$ of the annual average wage and causes congestion, fragmentation of districts, health risks and pollution. These high costs can be reduced by changes in the office systems. The present office system with commuting adds $40 \%$ to the average labor costs. The innovative office systems reduce these costs by 15 to $28 \%$ of the present offices. Sensitivity analyses underpin the findings for nearly all urban conditions. The local office systems are particularly cost-effective. The local office system can also save nearly $78 \%$ energy and reduce $74 \% \mathrm{CO}_{2}$ emission of the present offices along with less space use. Congestion, as well as fragmentation of communities and nature caused by commuting can be avoided.

Conclusions: Some project developers invest in the distributed offices. Policies encourage such investments if they reallocate funds from infrastructure into refurbishing of the available housing and internalize the external effects of land use in the costs of real estate development. These policies increase smartness of cities, reduce energy use, and improve living qualities in cities.
\end{abstract}

Keywords: Knowledge worker, Real estate, Commuting, Office, Innovation, Energy-related carbon dioxide emissions

\section{Highlights}

- Knowledge concentration fosters economic development but knowledge is diluted in the European cities

- Dislocation of offices and residential housing is the cause of the knowledge dilution and commuting

- The present offices system increased the annual average labor costs by about $40 \%$
- Alternative office systems save 15 to $28 \%$ of costs of the present offices systems

- Alternative office systems reduce up to $78 \%$ of energy use in the present office systems and $74 \%$ of $\mathrm{CO}_{2}$ emission

- Policies that foster the local offices system contribute to smart cities and sustainable development

Correspondence: y.krozer@utwente.nl; krozer@xs4all.nl

University of Twente, Jyothi Institute of Technology and Sustainable

Innovations Academy, p/a lepenplein 44, 1091JR Amsterdam, The

Netherlands 


\section{Background}

Throughout the last century, the share of knowledge work in total employment in high-income countries increased from close to nil percent to about twenty percent. Nearly all that knowledge work is located in cities. An observation is that this spatial concentration of artists, designers, teachers, scholars, engineers, managers, policy makers, and suchlike knowledge workers generates innovations entailing economic development. High density of various human capabilities in cities is supposed to foster innovation because innovators can generate expertise and stakeholders' support for business development [1-3]. A statistical analysis of the city employment in the USA during the period 1940-1990 confirms this viewpoint: growth of employment in the city colleges is associated with more employment in cities after corrections for other relevant factors. This employment growth is due to higher productivity and more leisure business in cities [4].

Based on this observation, spatial clustering of researchers and businesses is advocated $[5,6]$. The European policies have prioritized such clustering [7], less so in the USA and Japan. In Europe, many billions of euros public money is spend in Europe during 1990s on facilities coined as high-tech valleys, campuses and suchlike. The results were disappointing. Innovative activities, measured by patents, increased in the regions and businesses that received funds but the activities did not disseminate across regions and businesses $[8,9]$. Case studies of the business clusters show knowledge interactions beyond the regional contexts and little spatial interdependencies of businesses and experts because both are mobile [10, 11]. Subsidies hardly mattered for the firms' mobility [12, 13]. Policy priorities turned toward the stakeholders' networks coined as "Triple Helix" [14, 15]. The argumentation is that the networks of experts, businesses, policymakers, and social organizations can generate institutional arrangements that enable innovations even in regions with low innovative capabilities [16-18]. The stakeholders' networks in cities are funded under the label of "smart cities". The smart city, herewith, is conceptualized in broad sense as urban sustainable development based on human and social capital, communication, cultural and natural resources [19], as the sources of knowledge [20], as well as in the narrow business terms of information and communication services [21], and energy and environmental technologies [22]. This paper aims to support policies on smart cities. The smart city is comprehended as an urban concentration of knowledge workers.

The worrying issue is that indicators point out at the dilution of knowledge work in Europe. Data is shown in Appendix 1. The available data suggest that cities' smartness decreases. Firstly, the European population is aging, which reduces the networking ability. The share of people above 60 years old is $24.5 \%$ of all 504 million European Union inhabitants in the year 2012. This share increases faster that the population growth. The share of people in the studying age of 16-24 years decreases; it was $8 \%$ of all in 2012. Secondly, the expenditures on all education per inhabitant and on the tertiary education per student stagnate, and the expenditures on research and development decrease after correction for inflation (Eurostat). Third, and above all, urban life dilutes when measured by the number of people on an area. The built-in space in Europe grows by more than 8\% per year, which is about six times faster than the population growth or five times faster after correction for larger houses. Space around houses grows. The density of knowledge workers in cities decreases even faster because the knowledge institutions move out of the city centers toward city edges when these locations are cheap. If the stagnating knowledge work caused by the aging population and lower expenditures on the knowledge work are combined with the enlarging spaces around housing and moving out of the knowledge institutions, the dilution of knowledge work cities exceeds 8\% a year in Europe. This process evolves particularly fast in Austria, Belgium and Portugal. The direct effect of the diluting urban populations is growing commuting mileage. For example, every newborn European citizen might commute in 25 years about $170 \mathrm{~km}$ a day compared to the present $25 \mathrm{~km}$ daily average. The indirect effect is less frequent personal interactions, which reduces diversity of contacts. In addition to the negative social impacts, there are also environmental concerns, such as the growing energy use in commuting, space coverage, and pollution. With respect to pollution, carbon dioxide is particularly important because indicates impacts on climate change and impacts of fuel combustion on health and nature caused by smog, fine particles, and acidification.

The issue addressed in this paper is about possibilities of turning around the trend toward dilution of urban population, in particular the knowledge work in cities. The situation in the Netherlands is taken as an example and this situation is compared to other countries. The paper is focused on mitigating the commuting mileage because the aging and knowledge work trends are possibly even more difficult to revise than the dilution process. It is underpinned that changes in the spatial distribution of employment and housing are drivers of the commuting growth (section 2). It is also pinpointed that actions aiming to reduce high social costs of commuting are taken but commuting still grows (section 3). Then, a few alternative office systems are presented, which can turnaround the dilution process as being a step forward toward smarter cities (section 4). Thereafter, the social costs and benefits of the alternative office systems are presented (section 5). In addition, energy use and carbon dioxide emissions are estimated as indicators of environmental impacts (section 6). Finally, conclusions are drawn (section 6). 


\section{Real estate cycles}

The phenomenon of the diluting urban population, called urban sprawl, does not need introduction because it has attracted a lot of scholarly and media attentions in the USA [23-25], in Europe [26-28] and in Japan [29, 30]. The causes of urban sprawl, however, are heatedly disputed. In the mainstream economic view, the reason is growing demand for better housing and living. This demand, it is argued, invoked shifts toward the suburban areas that provide more space and other natural amenities. The demand would explain urban sprawl during 1950s and 1960s in the USA and Europe when income grew fast but the process went on during the subsequent decades of low income growth and even during recession, albeit slower in the USA [31]. The argument that the changing economic structure caused urban sprawl is more convincing. The major change was fast growth of services in the high-income countries from 1960s to 1980 s when the turnover of services grew 1.5-2.0\% per year faster than the income growth and slowed down thereafter (U.S. Department of Commerce, 1996). During the last fifty years, the share of services value in the GDP of high-income countries increased from about $40 \%$ in the 1960 s to nearly $75 \%$ in 2010 when about 64 percent of males and 82 percent of females were employed in services in the highincome countries (World Bank data). Although most service work is done individually they are concentrated in offices buildings. Nearly all knowledge work is done in offices. With regard to that growth of office work, urban sprawl during the last 50 years can largely be attributed to the outward shifts in locations of offices.

The shifts in locations of offices are driven by fluctuating office-housing prices. The fluctuations are explained by cyclic imbalances of demands and supplies on real estate markets. The imbalances emerge because it takes time before constructions can satisfy growing demands for housing entailing prices increase, and when the demands are saturated along with the prices drop the construction activities cannot stop immediately because of past commitments. Hence, the office-housing prices peak periodically [32]; some assume regularity of 10 years [33]. The price cycles of offices and residential housing evolve not simultaneously. While the cycles of office housing are driven by construction of offices, the cycles of residential housing are sensitive to the household income [34]. These two cycles have spatial impacts. During the peaking office-housing prices there is pressure to seeking for cheaper office locations outside city centers whereas the low prices make city centers attractive. Since people tend to live closer to work, constructions of the residential housing follow locations of offices when people income grows, i.e., with a time-lag. Even if policy aim to regulate the residential housing, as it is done in Europe, it can hardly influence urban sprawl because shifts in the offices locations bring people in motion. In the Netherlands, as a European example, demands for offices increased along with soaring prices when services expanded during 1960s. This process invoked constructions of offices on the city edges entailing residential satellites during 1970s. When the economic crisis of early 1980s hit the real estate markets many buildings became vacant along with price drop. Offices shifted to city centers and residents followed, which is branded as smart cities in the late 1990s. The economic boom of 1990s pushed up the office prices. Offices spread around entailing suburban residential housing until the financial crisis in 2008 hit the real estate. Similar process evolved in the USA [35]. As a result, in the USA, $42 \%$ of all offices were suburban in 1999 compared to $26 \%$ in 1979 , and about $37 \%$ of all office were "edgeless", meaning widely dispersed, compared to 38\% downtown [36]. Similar shifts can be observed in Europe and Japan but data is not found. Each cycle of the office real estate increased the distance between offices and residential areas because the vacant office-housing pauperize during low prices. The distance has generated more commuting by cars because the public transport (rail and road) and slow transport (biking and walking) are insufficient to reach the scattered areas. Commuting with the associated infrastructure and congestion, therefore, should be considered an external effect of the real estate market.

An alternative is use of information and communication technology for work on distance, called telework. Barriers are observed, such as social relations at work, pressures on wages, small space at home [37]. Hence, the telework evolves slowly in the rural areas despite tele-networks infrastructure [38]. It is also low in cities though high age and education are supportive to the telework $[39,40]$. The share of telework in the full-time employment is nearly nil in several European countries up to $3 \%$ in the Slovakia and Austria, $1.7 \%$ in the EU, and in the part-time employment from nil on Malta to $15.2 \%$ in Czech Republic compared to 7\% EU average; part-time jobs cover more than quarter of all and increase [41]. A lower share of telework in the total employment is observed in the United States where urban space is more diluted than in Europe [42, 43]. In the densely populated Japan, however, the population of telework in total employment was about $16.5 \%$ in 2010 , which is about twice higher than in Europe, and it is strongly promoted [44]. Dense population and facilitating policies, apparently, contribute to telework. The present 5\% annual growth of the telework in Europe [45] is hardly above the commuting growth rate. The present policies support the real estate markets with tax exemptions for loans, permits for new locations, funding of infrastructure and others. Also liabilities of developers for the land use, social disruption, environmental degradation and others 
negative external effects of the real estate markets on society are obstructed. The public interest is that the scale of offices and number of inhabitants in a municipality determines its income, which defines the politicians' position and clergy employment. Such policies improve income of project developers and institutions but enlarge the social costs of commuting. It is an institutional lock-in.

\section{Commuting mileage}

Commuting is usually by car five days a week. The commuting mileage grows faster than the total travel mileage. For example, in the Netherlands between 1985 and 2010 the annual travels including international ones have grown from 120 to $170 \mathrm{~km}$ per person but the share of commuting has grown from 21 to $34 \%$, mostly by car. The average commuting distance has increased from 12 to $18 \mathrm{~km}$ one way. By personal car it was on average $22 \mathrm{~km} 180$ days a year in 2010, based on Nationale Mobiliteit Monitor and CBS woon-werk statistiek. It is costly. The commuter's direct user cost is the transport cost, which is mainly car use. Typical car users spend about $€ 5$ 150 per person on the car depreciation, gasoline, insurance, maintenance and taxes, based on BerekenHet.nl, Autokosten, and [46], but not all depreciation and maintenance costs can be attributed to commuting. The indirect user costs are the travel costs, which cover road infrastructure, and travel time. The costs of road use per person are minimum $€ 70$ a year, own estimate based on [47]. The travel time is typically $50 \mathrm{~min}$ one way excluding incidental traffic jams, repairs and suchlike during 180 days a year. If the commuting time is an opportunity cost of $50 \%$ average wage, which is about $€ 16$ per hour, the travel costs are typically $€ 4800$ a year. In addition, there are non-user costs paid through collective arrangements for accidents, noise, and waste and so on. These social costs are estimated to be minimum $€ 470$ per person a year in Europe [48, 49]. The tangible social costs of a typical car commuter in the Netherlands approach $€ 10,490$ a year, which is about $22 \%$ of the average salaries. The dislocation of offices and residential housing costs nearly $€ 42$ billion a year, which is about $4.8 \%$ of the GDP. The four million Dutch commuters by car pay it directly or indirectly. There are also values that are not paid for. There are productivity losses in distribution, e.g. waiting time related to congestion. Welfare losses are stress, car accidents, pollution, impacts on climate and others. Social networks are disrupted when traffic moves through communities and nature is degraded when landscapes are fragmented by infrastructure.
Commuting with associated congestion is often considered an issue to be resolved within the domain of mobility through more roads and management of traffic flows. This viewpoint may reflect interests related to the mobility business but it does not address the cause of commuting, which dislocation on the real estate markets as mentioned above. Hence, the mobility improvements are ineffective despite many actions. The demand-side policies put tax on fuel and traffic, foster selective car use and pooling, restrict parking, regulate speed and flow, inform people, and so on. The supply-side policies enlarge infrastructure, improve public transport, limit traffic in some areas, discourage car ownership and improve traffic management, such as peak sharing. Technology policies foster fuel saving cars, telematics for routing, new logistic systems. Spatial planning aims at compact districts [50]. In addition, services are shared with drop-off points and bus transits, pedestrian, environmental, and low-traffic zones are created [51]. Shifts from individual car travels to mobility management are encouraged with tolls and road pricing [52]. Non-technical innovations are introduced [53], such as pricing of parking, public transport fares and taxes, regulations through access control, parking fleet, informing, carpooling, dial and ride, staggered activity time, tele-working, and infrastructure with park and ride, pedestrian and cycling zones, public transport, and ramp metering. The information and communications technology (ICT) use aim to shorten the commuting time because optimizes travels, access of locations, diversity of transport modes, enables multitasking and suchlike [54]. All these efforts have low impact on commuting entailing more congestion.

The commuting behavior is also addressed, such as more flexible swapping of homes to work locations and optimal routes planning. These would prevent $87 \%$ of the commuting mileage in the USA [55]. This argument is criticized for not accounting numerous trade-offs, such as different commuting destinations of couples and multi-functional travels to various locations because people make shopping, take kids from school and so on $[56,57]$ and for neglecting imperfections on route because of road works, accidents and other hinders [58]. Many people cannot swap when there is shortage on the real estate markets and when do not sense the costs because the commuting costs are compensated or exempted from taxes. If people have to pay these costs the suburban housing has lower property value [59].

\section{Office systems}

The institutional lock-in caused by the dislocation of offices and residential area is difficult to resolve but 
through innovations that reduce the imbalances on the real estate markets. The innovations can cluster offices and vice versa distribute them closer to homes. The social costs of these alternatives are compared to the present situation using life cycle costing [60]. In addition, impacts on energy use and the energy-related carbon dioxide emissions are assessed as being indicators of the external effects related to the dislocation.

The life cycle costing embraces methods aiming to estimate costs throughout production, distribution, consumption, and disposal of a system life time. The method of life cycle costing is often used for the cost assessments of capital goods, such as infrastructural works for electricity, water, roads, and buildings. The methodology and applications for capital goods can be found in several manuals [61-63]. This methodology is also elaborated for assessments of the sustainability issues and applications for consumer goods [64]. The system, herewith, is the office work with commuting. Solely the physical resources for the office work are estimated: accommodation space, materials, equipment and commuting. The labor and capital resources are considered constant. Performances are assumed equal. Four systems are compared. Four office systems are compared. The present system of offices covers offices of concentrated on the specific office areas though there are also offices spread in a city. Such Present office systems are considered to be the reference for comparison with three alternatives. Three available alternatives are assessed. One alternative system is the Mega office; it means high concentration of office work in a suburban area and commuting several kilometers more one way compared to the Present office mainly by public transport. Another one is the Local office: distributed sites for about 50 workplaces for rent on time basis and meeting points on a larger distance, accessible from homes by the slow transport (bikes and suchlike). Third alternative is the Home office: extra office space at home without commuting. The costs are assessed in euro per employee and in total for one million office employees, equivalent to an area of roughly three million inhabitants in the Netherlands. The office systems are schematically presented in Fig. 1.

The accommodation space is assessed with the statistics of offices and verified with a study on the space use of offices in the USA and the Netherlands [65]. Per person, the Present office is assumed to cover on average $35 \mathrm{~m}^{2}$ gross for work inside the building and $20 \%$ extra outside the building for car parking, travels and meetings at a third of the office square meter price. For the Mega office, the statistically observed largest scale office category is assumed. The space of Mega office per person covers $74 \%$ of the Present office space. A smaller space outside the building is assumed proportional to the lower car transport in all transport. The space of Local offices per person is assumed to be nearly $66 \%$ of the Present office. This is based on observations of absenteeism in offices because of meetings outside the office, sickness, vacation leaves and so on, which is observed in the statistics on the office work in the Netherlands. This lower space use is reflected in renting offices per time unit. For the Home offices the statistical smallest office per employee is used, which is $20 \mathrm{~m}^{2}$ gross at the Present office price. Main materials are energy and paper. Energy covers heating and

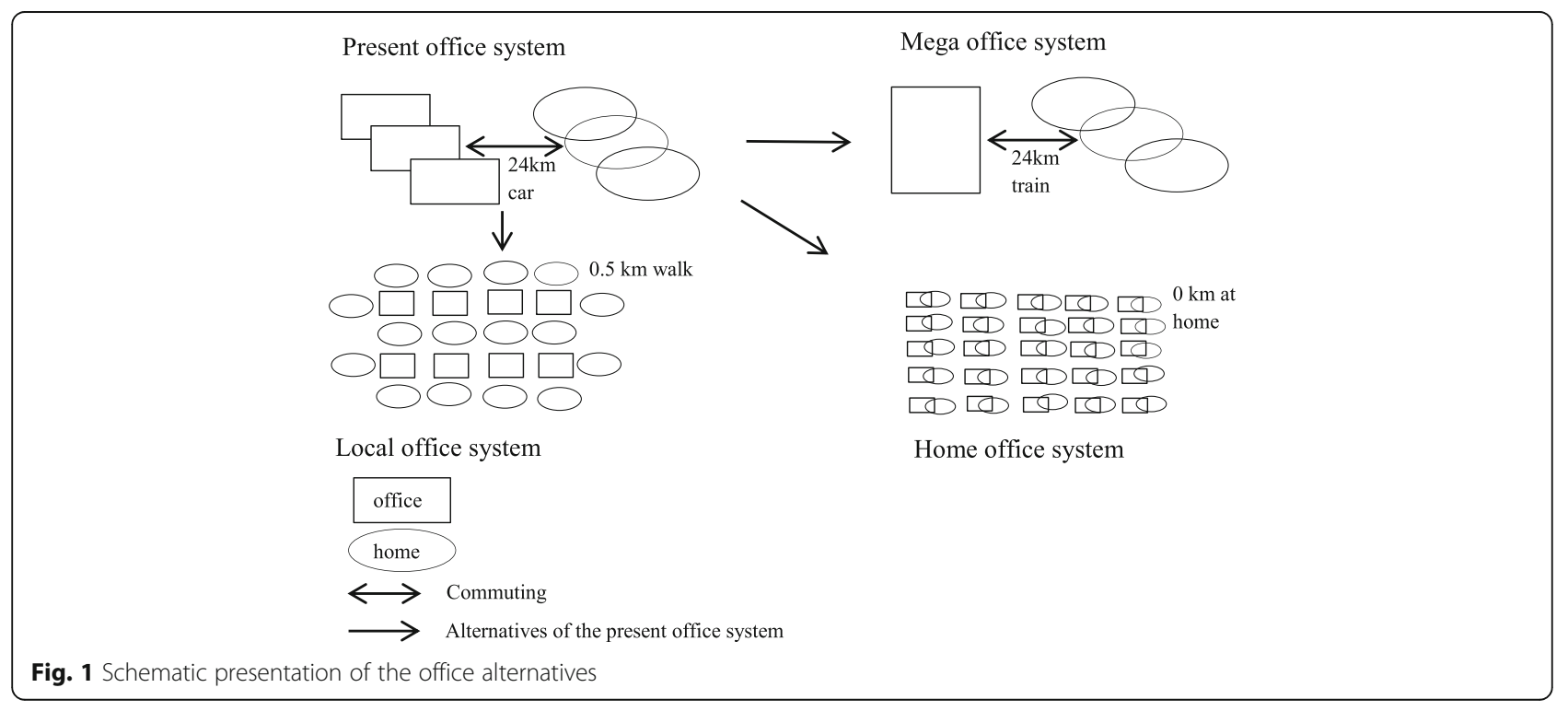


electricity for air conditioning, lighting and equipment. Statistical data on energy in the financial services is used. Compared to the Present offices, the Mega and Local offices are assumed to use less energy because of scale advantages respectively efficient space use, and the Home offices use more energy, which is based on very large, respectively small and very small offices in the statistical data. The main change in energy use reflects changes in air conditioning. The unit price of energy use is equal in all cases; in reality the large scale use is cheaper. The paper use per person during one year is based the German banks uses [66], which is about $175 \mathrm{~kg}$ per employee a year for the Present office. The Mega office is assumed to use $20 \%$ more paper for the internal communication. The Local offices use $7 \%$ less and the Home offices $40 \%$ less paper based on various offices in Germany. The same unit costs of paper are assumed.

The office equipment reflects the use in the Dutch technological institute (TNO), an organization with a few thousand employees (this information is highly appreciated). It covers furniture, ICT equipment, ICT experts and networks. All alternatives are assumed to use the Present office furniture and ICT, e.g., docking station, desktop monitor, laptop, laser printer, server, fax, repro copier, fast modem and networks (scale effects are neglected). For the Local offices 30\% less furniture and ICT equipment per employee are assumed but faster depreciation due to the timesharing. The costs of network are assumed higher for the Local and Home offices. Hence, the ICT unit costs in the Local offices are higher, which is a prudent assumption because the present ICT utilization rate in offices is lower. The costs of the ICT services in the Present system are estimated based on the average work and travel time of an ICT expert at the institute, which is one expert per 38 work units. This is also assumed for the Mega office. For the Local offices only 30 work units per ICT expert are assumed because of extra travels and care and for the Home offices additional 15\% costs because they must make longer travels. A high salary of the ICT experts is taken.

The commuting costs are transport costs (means) and travel costs (time loss). The transport is assessed with the transport statistics. The train and car costs per kilometer are data delivered by the public transport enterprises and automobile associations. The unit cost of bicycles is a best guess. The cost of walking is neglected. The average speed is assessed per transport mode for a few commuting routes. It is $50 \mathrm{~min}$ one way trip by car at $24 \mathrm{~km}$ per hour average speed. The trains are faster but include walking. Biking is slower but travels are shorter. The transport costs exclude car depreciation because cars are used for various activities. For the Present offices 55\% of workers use car, $10 \%$ public transport subdivided into train, bus and metro, $30 \%$ bicycles and $5 \%$ are pedestrian. For the Mega offices $80 \%$ of workers use public transport and $20 \%$ car. The Local offices are reached by biking and walking, each one by $50 \%$ of the employees. The Home offices have no commuting. Per trip the average transport costs vary from $€ 3$ for the Present offices up to $€ 7$ for the Mega office because of the larger distances, no slow transport but public transport. Reaching the Local office is low cost. The travel costs are travel time times $€ 16$, i.e., $50 \%$ of the hourly average wage. Basic data is in Appendix 2. Table 1 summarized key variables of the alternatives.

\section{Life cycle costs of the office systems}

Table 2 shows the life cycle costs per employee: the office systems in columns, the total costs of the office work and commuting with the main cost factors as percentage of the totals in rows. The Present office work costs annually about $€ 23,400$ per employee.

Table 1 Main input variables of the alternative office systems

\begin{tabular}{lllll}
\hline Data per year per person & Present & Mega & Local & Home \\
\hline Space, $\mathrm{m}^{2}$ & $\begin{array}{l}35+20 \% \\
\text { outdoor }\end{array}$ & $\begin{array}{l}74 \% \text { of the } \\
\text { present }\end{array}$ & $\begin{array}{l}66 \% \text { of the } \\
\text { present }\end{array}$ & 20 \\
Energy us, MWh & 12 & 9 & 4 & 13.6 \\
Paper use, kg & 175 & 209 & 163 & 116 \\
Informatics support, $\mathrm{h}$ & 46 & 46 & 59 & 69 \\
Travel distance, km & 3127 & 7920 & 270 & 0 \\
Travel time, $\mathrm{h}$ & 123 & 118 & 41 & 0 \\
\hline
\end{tabular}

Table 2 Life cycle costs of the office systems

\begin{tabular}{lllll}
\hline Main cost factors & $\begin{array}{l}\text { Present } \\
\text { office }\end{array}$ & $\begin{array}{l}\text { Mega } \\
\text { office }\end{array}$ & $\begin{array}{l}\text { Local } \\
\text { office }\end{array}$ & $\begin{array}{l}\text { Home } \\
\text { office }\end{array}$ \\
\hline Total costs in $€$ & 23,384 & 19,892 & 18,150 & 16,840 \\
Total cost saving & 0 & $12 \%$ & $22 \%$ & $28 \%$ \\
Cost factors & $44 \%$ & $37 \%$ & $44 \%$ & $43 \%$ \\
$\quad$ Space & $15 \%$ & $18 \%$ & $21 \%$ & $23 \%$ \\
Materials & $16 \%$ & $19 \%$ & $27 \%$ & $34 \%$ \\
Equipment & $76 \%$ & $75 \%$ & $91 \%$ & $100 \%$ \\
Subtotal & 17,736 & 14909 & 16,582 & 16,840 \\
Work related in $€$ & $5 \%$ & $12 \%$ & $0 \%$ & $0 \%$ \\
Transport & $19 \%$ & $13 \%$ & $9 \%$ & $0 \%$ \\
Travel & $24 \%$ & $25 \%$ & $9 \%$ & $0 \%$ \\
Subtotal & 5649 & 4983 & 1568 & - \\
Commuting related $€$ & & & &
\end{tabular}


These costs add to about $€ 60,000$ annual average costs of labor in 2015 in the Netherlands. The alternatives are cheaper: the Mega office work $12 \%$, the Local office $22 \%$ and Home offices $28 \%$. The most costly factor in all cases is the accommodation, which is $43 \%$ of the total costs, but $37 \%$ of the Mega office costs due to the higher density. The costs of energy and paper cover about 15\% of the Present offices costs but they are higher in all alternatives up to $23 \%$ of the Home office costs. The equipment costs, in particular the ICT services, increase from $16 \%$ of the Present offices costs up to $27 \%$ of the Local offices and even $34 \%$ of the Home offices costs. Compared to the Present offices, the Mega offices are 15\% cheaper due to its higher density; and the Local and Home offices are 7 and 5\% cheaper than the latter because the lower accommodation costs outweigh the extra costs of ICT. Due to much biking and walking in the Netherlands the transport costs are only $5 \%$ of the total life cycle costs of the Present offices. This share is presumably higher in the thinly populated countries and in the countries with little slow transport. The travel costs are 19\% of the life cycle costs. The Mega office may cause higher transport costs but lower travel costs thanks to more public transport and shorter travel time. The commuting costs to Local offices and Home offices are low, respectively, nil (Table 2).

Table 3 shows the annual costs of one million office workers. For the Local and Home offices, one

Table 3 Life cycle costs for one million employees with sensitivity analyses

\begin{tabular}{lllll}
\hline In $€$ billion a year & $\begin{array}{l}\text { Present } \\
\text { office }\end{array}$ & $\begin{array}{l}\text { Mega } \\
\text { office }\end{array}$ & $\begin{array}{l}\text { Local } \\
\text { office }\end{array}$ & $\begin{array}{l}\text { Home } \\
\text { office }\end{array}$ \\
Space use & 10.3 & 7.4 & 7.9 & 7.2 \\
Material costs & 1.2 & 1.3 & 0.9 & 0.9 \\
ICT costs & 6.2 & 6.2 & 7.7 & 8.7 \\
Transport costs & 1.2 & 2.5 & 0.0 & 0.0 \\
Travel costs & 4.5 & 2.5 & 1.6 & 0.0 \\
Total & 23.4 & 19.9 & 18.2 & 16.8 \\
Savings & 0.0 & 3.5 & 5.2 & 6.5 \\
Sensitivity analysis & \\
& Present & Mega & Local & Home \\
Reference life cycle cost & 100 & 86 & 81 & office \\
50\% cheaper space & 100 & 89 & 78 & 73 \\
No travel costs & 100 & 93 & 91 & 95 \\
150\% ICT wages & 100 & 86 & 81 & 78 \\
Combination ${ }^{b}$ & 100 & 100 & 96 & 103 \\
\hline
\end{tabular}

Index relative to the total life cycle costs

${ }^{\mathrm{b}}$ Combination of cheaper space, no travel costs and high ICT wage million teleworkers in the Netherlands would bring this country close to the top of countries' telework in Europe. The office alternatives are in columns, the main costs in rows. The Present office system costs about $€ 23$ billion per million employees per year. The Mega offices can save about $€ 3.5$ billion, the Local ones about $€ 5.2$ billion and the Home offices about $€ 6.5$ billion, excluding car depreciation and maintenance, waiting time in traffic jams and the social costs of external effects. Four sensitivity analyses are made. One is $50 \%$ cheaper office space, e.g., in peripheries. Second is no travel costs, e.g., people do not mind time. Third are extra ICT service costs, e.g., high demand for experts. Fourth is a combination of all. The sensitivity analyses confirm the cost savings, but the combination of all is costly for the Home offices though each separate factors in the sensitivity analysis is lower costs. This is because the costs of energy, paper, and ICT equipment in the Home offices remain high. The Local offices system is the most cost-effective alternative.

Table 4 Energy use and carbon dioxide emission $\left(\mathrm{CO}_{2}\right)$ of the office alternatives

\begin{tabular}{|c|c|c|c|c|}
\hline In kWh/year & Present & Mega & Local & Home \\
\hline \multicolumn{5}{|l|}{ Offices } \\
\hline Lighting & 1468 & 1299 & 812 & 1468 \\
\hline Air conditioning electric & 991 & 932 & 485 & 1109 \\
\hline Air conditioning gas & 8900 & 6261 & 2236 & 10,364 \\
\hline Equipment & 622 & 523 & 361 & 684 \\
\hline Subtotal office use & 11,981 & 9014 & 3894 & 13625 \\
\hline Subtotal office energy reduction & $0 \%$ & $25 \%$ & $67 \%$ & $-14 \%$ \\
\hline \multicolumn{5}{|l|}{ Transport } \\
\hline Car & 4442 & 3397 & 0 & 0 \\
\hline Train & 97 & 760 & 0 & 0 \\
\hline Subtotal transport energy reduction & 4539 & 4157 & 0 & 0 \\
\hline Total MWh per person & 16.5 & 13.2 & 3.9 & 13.6 \\
\hline Energy reduction & $0 \%$ & $20 \%$ & $76 \%$ & $18 \%$ \\
\hline \multicolumn{5}{|l|}{ CO2 kg per year per person } \\
\hline Office electricity & 511 & 383 & 163 & 582 \\
\hline Office gas & 134 & 95 & 34 & 157 \\
\hline Car & 128 & 98 & 0 & 0 \\
\hline Train & 4 & 33 & 0 & 0 \\
\hline Total kg/year & 777 & 608 & 197 & 738 \\
\hline Percent of typical $\mathrm{CO}_{2}$ per capita ${ }^{a}$ & $7.4 \%$ & $5.8 \%$ & $1.9 \%$ & $7.0 \%$ \\
\hline Emission reduction & $0 \%$ & $22 \%$ & $75 \%$ & $5 \%$ \\
\hline
\end{tabular}




\section{Energy}

All alternatives office systems eliminate congestion. The distributed offices systems of Local and Home offices also reduce space use in cities to about half of the present offices because cars do not need parking places at home and at offices. In addition, energy saving and reduction of carbon dioxide emission are feasible. The embodied energy in buildings is relevant as it exceeds $200 \mathrm{GJ}$, i.e., $55 \mathrm{MWh}$, for a $50 \mathrm{~m}^{2}$ office compared to about $5 \mathrm{MWh}$ a year for the office work [67]. The embodied energy, however, is not included because it is not directly related to work and the materials' embodiment varies [68]. The office work covers four components: electricity for lighting, air condition and equipment and gas use for air conditioning. The commuting covers energy use for cars and trains; other types of communication are neglected because their shares in total are low. Slow transport by walking and biking is assumed to be free of energy use because fuels are not involved. Table 4 shows the energy use and energyrelated carbon dioxide emissions of the office alternatives.

The energy use of a typical office worker in the present offices is about 4.4 MWh per year, which is mainly for heating and lighting. Equipment is a minor user. In addition, such worker uses about $4.5 \mathrm{MWh}$ for commuting. Together this is about twice as much as a typical city inhabitant at home. The Mega offices can reduce about $11 \%$ of the energy use. About half of this reduction is due to the assumption about smaller offices. Another half is due to substitution of rail for car driving. The Local offices can save about $78 \%$ of the Present offices energy use. Slow transport is important. Nearly $53 \%$ can be saved when offices are efficiently used. The energy savings of the Home offices is $49 \%$ because transport is not needed but more energy is used at home. These results are reflected in carbon dioxide emissions. An office worker in the present offices causes about $313 \mathrm{~kg}$ carbon dioxide emission per year. In the Netherlands, it is about 3\% of all carbon dioxide per capita. The Mega office reduces $10 \%$ of this emission, the Local offices about $74 \%$ of them and the reduction percentage of the Home office systems is in-between.

\section{Conclusions}

Possibilities of fostering smart cities are discussed given that concentration of knowledge workers in cities generates innovations entailing economic development. The issue is that constructing new office and residential housing in suburbs is often more attractive to project developers than upgradation of the existing one in cities. The dislocation of offices and residential areas caused by imbalances on the real estate markets dilutes knowledge work and enlarges commuting, which undermines policies aiming the smart cities. Next to the direct social costs of commuting, which approaches $22 \%$ of the annual average salary, there are losses in productivity of distribution and welfare losses in the urban communities and in nature. These losses are unpaid external effects of the real estate markets. Changes of the office systems reduce the social costs and generate knowledge work in cities. The life cycle costs of the Present office system are higher compared to three alternative systems: concentration in Mega offices, distribution in Local offices or dispersion in Home office. The costs of office work and commuting can be reduced compared to the Present offices. The cost savings per million office employees approach $€ 3.5$ billion for the Mega offices, to $€ 5.2$ billion for the Local offices up to $€ 6.5$ billion for the Home offices. The Mega office systems have scale advantages in accommodation and public transport. The Local offices systems use space efficiently and reduce commuting to nearly nil, which outweighs the additional ICT costs needed to facilitate such distributed office system. The Home offices systems have nil commuting, which outweighs the costs of the extra office space at home and high ICT costs. The outcome is robust for the low cost of space, costless travel time and high ICT costs. The low cost Local offices are robust under various conditions. About 74\% energy and carbon dioxide emissions can be reduced through the Local office systems because they use the office space efficiently and do not need fuels for commuting. It is a net beneficial way of mitigating climate change. Trend toward the Local office systems is observed in cities across countries. These systems are expressed in cafes, restaurants and suchlike where people do office works. This way, the city centers are recaptured by knowledge workers. Project development can tune offices to this diversity of locations for knowledge work, which upgrades assets of the public spaces in cities. Institutional barriers impede the shift to the alternatives because real estate markets are not liable for the external effects of imbalances on the real estate markets. Policies can foster the trend toward more knowledge work in cities when they impose liabilities for the external effects of the real estate markets through permits, taxes on land, and compensations for harms caused by the real estate development. It may increase costs of projects but gives a boost to the smart cities. 


\section{Appendix 1}

Table 5 The European Union data on population, expenditures, and space use (data in 2012)

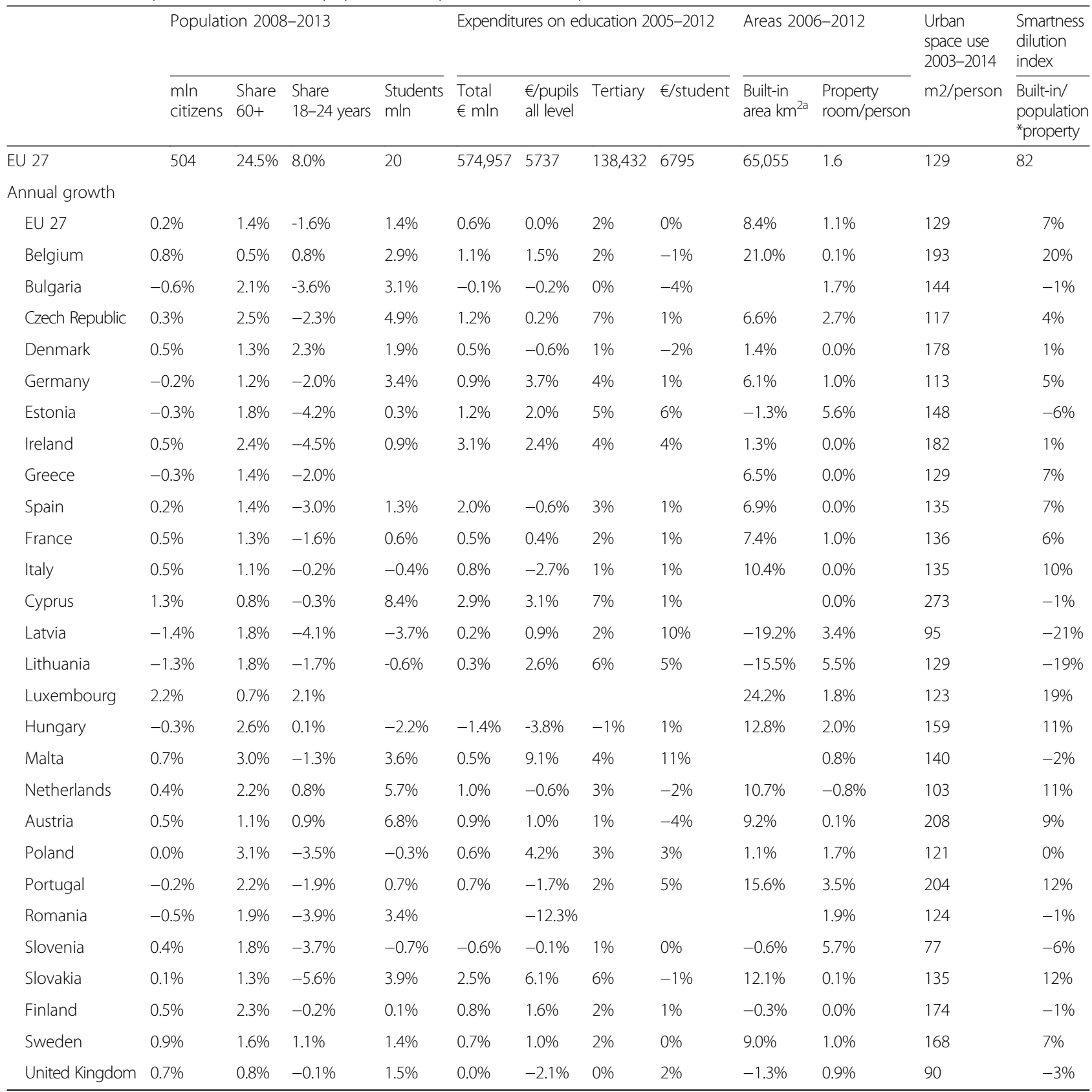

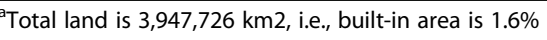




\section{Appendix 2}

Table 6 Space and costs of offices working place

\begin{tabular}{|c|c|c|c|c|}
\hline Working place $\left(€ / \mathrm{m}^{2}\right)$ & Present office & Mega office & Local office & Home office \\
\hline Work place gross & 35 & 26 & 23 & 20 \\
\hline Parking & 23 & 13 & 0 & 0 \\
\hline Others & 11 & 8 & 5 & 4 \\
\hline Total & 69 & 47 & 28 & 24 \\
\hline Work place (230) & 7976 & 5991 & 5324 & 4608 \\
\hline Parking (69) & 1563 & 884 & 0 & 0 \\
\hline Others (69) & 791 & 536 & 319 & 276 \\
\hline Total costs & 10,329 & 7411 & 5643 & 4885 \\
\hline Home, $\mathrm{m}^{2}$ (184) & 46 & 46 & 46 & 46 \\
\hline Public space $\mathrm{m}^{2}$ & 97 & 97 & 130 & 130 \\
\hline Public space (69) & & & 2304 & 2304 \\
\hline Office and living & 10,329 & 7411 & 7947 & 7189 \\
\hline Index & 100 & 72 & 77 & 70 \\
\hline Additional costs & & -2919 & -2382 & -3140 \\
\hline
\end{tabular}

Table 7 Costs of offices equipment

\begin{tabular}{lllll}
\hline Equipment & Present office & Mega office & Local office & Home office \\
\hline Depreciation & 1157 & 1157 & 1258 & 1009 \\
extra network centers & 0 & 0 & 441 & 441 \\
extra network district & 0 & 0 & 248 & 274 \\
Interest & 208 & 388 & 4866 & 573 \\
Labor costs & 3842 & 3942 & 393 & 393 \\
Software & 393 & 393 & 11 & 11 \\
Lease costs copier & 11 & 11 & 424 & 636 \\
Furniture & 636 & 636 & 7733 & $\mathbf{8 7 2 9}$ \\
Total & 6248 & 6248 & $124 \%$ & $140 \%$ \\
Index & $100 \%$ & $100 \%$ & 1486 & 2481 \\
Additional costs & & &
\end{tabular}


Table $\mathbf{8}$ Costs of offices materials

\begin{tabular}{|c|c|c|c|c|}
\hline & Present office & Mega office & Local office & Home office \\
\hline \multicolumn{5}{|l|}{ Paper use kg/year } \\
\hline Printing paper & 109 & 130 & 101 & 72 \\
\hline Packing & 39 & 46 & 36 & 26 \\
\hline $\begin{array}{l}\text { Newspaper } \\
\text { and books }\end{array}$ & 16 & 19 & 15 & 10 \\
\hline Sanitary paper & 5 & 6 & 5 & 3 \\
\hline Others & 7 & 8 & 7 & 5 \\
\hline Total use & 175 & 209 & 163 & 116 \\
\hline Costs $(€ 4,6 / \mathrm{kg})$ & 806 & 963 & 753 & 535 \\
\hline Index & 100 & 119 & 93 & 66 \\
\hline \multicolumn{5}{|l|}{ Energy use } \\
\hline Additional costs & & 157 & -54 & -272 \\
\hline Lighting kWh & 1468 & 1299 & 812 & 1468 \\
\hline $\begin{array}{l}\text { Air condit. } \\
\text { Electric. kWh }\end{array}$ & 991 & 932 & 485 & 1109 \\
\hline $\begin{array}{l}\text { Air condit. gas } \\
\mathrm{m}^{3} / \text { year }\end{array}$ & 915 & 644 & 230 & 1066 \\
\hline Office equipment & 622 & 523 & 361 & 684 \\
\hline $\begin{array}{l}\text { Total energy } \\
\text { use, GJ/year }\end{array}$ & 53.2 & 39.5 & 16.5 & 60.8 \\
\hline Lightning in $€$ & 101 & 89 & 56 & 101 \\
\hline $\begin{array}{l}\text { Air condit. } \\
\text { electric }\end{array}$ & 68 & 64 & 33 & 76 \\
\hline Air condit. gas & 141 & 99 & 35 & 164 \\
\hline Office equipment & 43 & 36 & 25 & 47 \\
\hline Total in $€$ & 352 & 288 & 149 & 388 \\
\hline Index & 100 & 82 & 42 & 110 \\
\hline Additional costs & & -18 & -58 & 10 \\
\hline
\end{tabular}

Table 9 Data on commuting to offices

Mobility in office alternatives, 180 days * two trips in present, Mega and Local offices

\begin{tabular}{|c|c|c|c|c|}
\hline & $\begin{array}{l}\text { Present } \\
\text { office }\end{array}$ & $\begin{array}{l}\text { Mega } \\
\text { office }\end{array}$ & $\begin{array}{l}\text { Local } \\
\text { office }\end{array}$ & $\begin{array}{l}\text { Home } \\
\text { office }\end{array}$ \\
\hline \multicolumn{5}{|l|}{ Cars } \\
\hline Time minutes & 51 & 21 & 0 & 0 \\
\hline Distance km & 21 & 44 & 0 & 0 \\
\hline Travel cost $€$ & 16 & 7 & 0 & 0 \\
\hline Transport cost $€$ & 5 & 10 & 0 & 0 \\
\hline Percent commuters & $55 \%$ & $20 \%$ & $0 \%$ & $0 \%$ \\
\hline \multicolumn{5}{|l|}{ Public transport } \\
\hline Time minutes & 44 & 44 & 0 & 0 \\
\hline Distance km & 44 & 44 & 0 & 0 \\
\hline Travel costs $€$ & 7 & 7 & 0 & 0 \\
\hline Transport costs $€$ & 6 & 6 & 0 & 0 \\
\hline Percent commuters & $10 \%$ & $80 \%$ & $0 \%$ & $0 \%$ \\
\hline \multicolumn{5}{|l|}{ Bicycle } \\
\hline Time minutes & 26 & 0 & 9 & 0 \\
\hline Distance km & 4 & 0 & 2 & 0 \\
\hline Travel costs $€$ & 8 & 0 & 3 & 0 \\
\hline Transport costs $€$ & 0 & 0 & 0 & 0 \\
\hline Percent commuters & $31 \%$ & $0 \%$ & $50 \%$ & $0 \%$ \\
\hline \multicolumn{5}{|l|}{ Pedestrians } \\
\hline Time minutes & 16 & 0 & 18 & 0 \\
\hline Distance km & 1 & 0 & 2 & 0 \\
\hline Travel costs $€$ & 5 & 0 & 6 & 0 \\
\hline Transport costs $€$ & 0 & 0 & 0 & 0 \\
\hline Percent commuters & $4 \%$ & $0 \%$ & $50 \%$ & $0 \%$ \\
\hline Total & $100 \%$ & $100 \%$ & $100 \%$ & $0 \%$ \\
\hline \multicolumn{5}{|l|}{ Costs $€$} \\
\hline Travel cost per trip & 12 & 7 & 4 & 0 \\
\hline Travel costs per year & 4468 & 2512 & 1555 & 0 \\
\hline Transport costs per trip & 3 & 7 & 0 & 0 \\
\hline Transport costs per year & 1181 & 2471 & 12 & 0 \\
\hline Total per trip & 16 & 14 & 4 & 0 \\
\hline Total annual $(*)$ & 5649 & 4983 & 1568 & 0 \\
\hline Index & 100 & 88 & 28 & 0 \\
\hline Costs & & -666 & -4081 & -5649 \\
\hline
\end{tabular}




\section{Acknowledgements}

This paper is largely based on the book Theories and Practices on Innovating for Sustainable Development, published by Springer. I am grateful for permission to present this paper. I have also appreciated comments of Dagmar Fiedler on the earlier version and valuable remarks of two unknown referees on the draft version. Many thanks to Avinash Narayanaswamy for correcting the English used in this manuscript. All deficiencies in the paper are my responsibility. This paper is based on a chapter in Krozer Y, 2015, Theories and Practices on Innovating for Sustainable Development, Springer, Heidelberg/New York. I am grateful to Springer for permission to use this material.

\section{Authors' information}

Yoram Krozer (1953) received MsC in biology, MA in Economics at the University of Utrecht, Business Administration at the Amsterdam Technical College and PhD in Economics at the University of Groningen. His work started at non-governmental organizations, then shifted to industries, and he directed the Institute for Applied Environmental Economics - TME. After 20 years in business he joined the University of Twente as Director of the Cartesius Institute, Institute for Sustainable Innovations of the Netherlands Technical University. He is associated professor at the University of Twente, professor at the CIIRC of the Jyothi Institute of Technology in India, Honorary Fellow at the Melbourne University and Director of the Sustainable Innovations Academy. His work is on economics of sustainable development. He has co-created eco-design products, software, masters and vocational courses, published nearly hundred papers and two books "Innovations and the Environment" and "Theories and Practices on Innovations for Sustainable Development".

\section{Competing interests}

The author declares that he has no competing interests.

\section{Received: 20 September 2016 Accepted: 6 January 2017} Published online: 27 February 2017

\section{References}

1. Malecki EJ (1991) Technology and Economic Development. John Wiley and Sons, New York

2. Freeman C (1996) The greening of technology and models of innovation. Technol Forecast Soc Chang 53:27-39

3. Florida R (2002) The Rise of the Creative Class. Basic books, New York

4. Shapiro J (2006) Smart Cities: Quality Of Life, Productivity, and the Growth Effects of Human Capital. Rev Econ Stat 88(2):325-335

5. Rosenfeld SA (1997) Bringing Business Clusters into the Mainstream of Economic Development. Eur Plan Stud 5(1):1-22

6. Porter ME (2000) Location, Competition and Economic Development. Econ Dev Q 14(1):15-34

7. Laffitte P (2006) High Level Advisory Group on Clusters, The European Cluster Memorandum

8. Baptista R, Swann P (1998) Do Firms in clusters innovate more? Res Policy 27:525-540

9. Moreno R, Paci R, Usai S (2005) Geographical and sectoral clusters of innovation in Europe. Ann Reg Sci 39(4):715-739

10. Malmberg A, Maskell P (2002) The elusive concept of localization economies: towards a knowledge-based theory of spatial clustering. Environ Plan A 34(3):429-449

11. Martin R, Sunley P (2003) Deconstructing clusters: chaotic concept or policy panacea? J Econ Geogr 3:5-35

12. Martin P, Mayer T, Mayneris F (2008) Concentration and Firms Level productivity in France. Centre for Economic Policy Research, Paris

13. Webb W (2008) Can Regional Cluster Be Engineered. Ingenia 34:43-46

14. Lawson C, Lorenz E (1998) Collective learning, Tacit Knowledge and Regional Innovative Capacity. Reg Stud 33(4):305-317

15. Etzkowitz $H$, Leydesdorff $L$ (2000) The dynamics of innovation: from National Systems and "Mode 2" to a Triple Helix of university-industrygovernment relations. Res Policy 29:109-123

16. Cooke P, Morgan K (2002) The Associational Economy, Firms, Regions, and Innovation. Oxford University Press, New York

17. Hospers G-J (2004) Regional economic change in Europe: a neo-Schumpeterian vision. Volkswirtschaft LIT, Munster

18. Florida R (2005) The Flight of the Creative Class. HarperCollins Business, New York

19. Caragliu A, de Bo C, Nijkamp P (2009) Smart Cities in Europe. J Urban Technol 18(2):65-82
20. Lombardi $P$ (2011) New Challenges in the evaluation of Smart Cities. Network Ind Q 13(3):8-10

21. Brauer B, Eisel M, Kolbe L M (2015) The State of the Art in Smart City Research - A Literature Analysis on Green IS Solutions to Foster Environmental Sustainability. PACIS 2015 Proceedings. Paper 74. Accessed 14 Sep 2016 http://aisel.aisnet.org/pacis2015/74

22. de Nucci MR, Spitzbart C (2010) Concerto, Socioeconomic impact assessment report - Executive Summary, Osterreichisches Forschungs- und Prufzentrum Arsenal GesmbH, Wien, 2010

23. Glaeser EL, Kolko J, Saiz A (2000) Consumer Cities. National Bureau of Economic Research, Cambridge Massachusetts, working paper 7790

24. Glaeser E L, Kahn M E (2001) Decentralized employment and the transformation of the american cities. National Bureau of Economic Research, Cambridge Massachusetts, working paper 8117

25. Glaeser EL, Kahn ME (2003) Sprawl and Urban Growth. In: Henderson JV Thisse J-F (eds) Handbook of Urban and Regional Economics IV, 1st edn. Amsterdam, Elsevier, pp 2481-2527

26. Chin N (2002) Unearthing the roots of urban sprawl: a critical analysis of form, function and methodology. Centre for Advanced Spatial Analysis, Paper 47 - Mar 02, London.

27. Dieleman F, Wegener M (2004) Compact City and Urban Sprawl. Built Environ 30(4):308-323

28. EEA (2016) Urban sprawl in Europe. European Environmental Agency Report 11/2016, Copenhagen

29. Pernice R (2007) Urban Sprawl in Postwar Japan and the Vision of the City in the Urban Theories of Metabolists. J Asian Architecture Build Eng 16(11):237-244

30. Okata J, Murayama A (2010) Tokyo's Urban Sprawl, Urban Form and Sustainability. In: Sorensen A, Okata J (eds) Megacities, Urban Form, Governance and Sustainability. Springer, London

31. Burchfield M, Overman HG, Puga D, Turner MA (2006) Causes of Urban Sprawl: Portrait from the Space. Q J Econ 2006:597-633

32. Lang RE, Sanchez WT, Oner AC (2009) Beyond the Edge: Office Geography in New Metropolis. Urban Geogr 30(7):726-755

33. Lee C (2011) Real Estate Cycles: They Exist..., They are Predictable. Center Real Estate Q J 5(2):5-11

34. Wheaton WC (1999) Real estate "cycles": Some fundamentals. Estate Econ 27(2):209-230

35. Zhu H (2002) The case of the missing commercial real estate cycle. BIS Q Rev; 56-66, http://www.bis.org/publ/r_qt0209g.pdf. Accessed 8 Feb 2017.

36. Lang RE (2000) Office Sprawl: The Evolving Geography of Business. The Brookings Institution, Survey Series, Washington, D.C

37. van Riesen F (1997) Ruim baan door telewerken. Nederlandse Geografische studies, Utrecht/Delft

38. Grimes S (2000) Rural areas in information society: diminishing distance or increasing learning capacity. J Rural Stud 16:13-21

39. de Graaff T (2004) On the Substitution and Complementarity between Telework and Travel: A Review and Application, Free University report

40. de Graaff TP, Rietveld P (2007) Substitution between out-of home and at home Work: the role if ICT and commuting costs. Transp Res A 41:142-160

41. European Foundation for the Improvement of Living and Working Conditions (2010) Telework in the European Union. Dublin, information@eurofound.europa.eu

42. Telecommuting (2014) http://globalworkplaceanalytics.com/telecommutingstatistics. Accessed 20 Nov 2014

43. Global Workplace Analytics, http://globalworkplaceanalytics.com/ telecommuting-statistics. Accessed 18 Feb 2016

44. MIC (2011) Efforts to promote telework in Japan. Ministry of Internal Affairs and Communication. Accessed on 14 Sep 2016 http://www.soumu.go.jp/ main_sosiki/joho_tsusin/eng/presentation/pdf/110908_1.pdf

45. Vitola A (2012) Overview on the European Policies on Telework. Intereg IVc, Alborg

46. Milieucentraal, https://www.milieucentraal.nl/vervoer/fiets-ov-of-auto/. Accessed 18 Feb 2016

47. Archer C, Glaister S (2006) Investing in Roads, Pricing, Costs and New Capacity. mimeo, Imperial College London

48. Essen van $H$, Schroten A, Otten M, Sutter D, Schreyer C, Zandonella R, Maibach M, Doll C (2011) External Costs of Transport in Europe. CE, Delft report

49. Korzhenevych A, Denhe N, Bröcker J, Holtkamp M, Meier H, Gibson G, Varma A Cox V (2014) Update of the Handbook on the External Costs of Transport. Ricardo-AEA, London 
50. Nijkamp P (1994) Roads toward environmentally sustainable transport. Transport Res A 28A(4):261-271

51. Goldman T, Gorham R (2006) Sustainable Urban Transport: Four Innovative Directions. Technol Soc 26:261-273

52. Nykvist $B$, Whitemarsh $L$ (2008) A multi-level analysis of sustainable mobility transition, Niche development in UK and Sweden. Technol Forecast Soc Chang 75:1373-1387

53. Hyard A (2013) Non-technological innovations for sustainable transport. Technol Forecast Social Change 80:1375-1386

54. Wee van B, Chorus C (2009), Accessibility and ICT: a review of literature, conceptual model and research agenda. Delft Technical University, paper BIVEC-GIBET day, Brussels

55. Hamilton BW (1982) Wasteful Commuting. J Polit Econ 90:1035-1053

56. White M (1977) A model of Residential Location Choice and Commuting by Men and Women Workers. J Reg Sci 17(1):41-52

57. White M (1988) Location Choice and Commuting Behavior in Cities with Decentralized Employment. J Urban Econ 24:129 - 152

58. Small KA, Song S (1992) "Wastefull" Commuting: A Resolution. J Polit Econ 100(4):888-898

59. Yi TC, Chan AWH (2003) Estimating the commuting cost and commuting time property price gradients. Reg Sci Urban Econ 33(6):745-767

60. van der Enk R, ten Houten RM, Krozer Y (1999) Kosten van kantoorconcepten., TNO Delft report

61. Dhillon BS (1989) Life-cycle costing. OPA, Amsterdam

62. Fabrycki WS, Blanchard BS (1991) Life-cycle cost and economic analysis. Prentice Hall Inc., New Jersey

63. Booz-Allen and Hamilton (1999) California Life Cycle Benefit-Cost Analysis Model. Department of Transportation, California

64. Krozer Y (2008) Innovations and the Environmental, 1st edn. Springer, London

65. Bisseling T (1998) Alternatieve werkplekken: de eerste harde cijfers. FACIO 12:9-12

66. Rauberger R (1996) Environmental Reporting: The Vfu-case of Benchmarking with Environmental Indicators in the Banking sector (internal report)

67. Reddy BW (2004) Sustainable building technologies. Curr Sci 87(7):899-907

68. Kumar A, Buddhi D, Chauhan DS (2011) Indexing of Building Materials with Embodied, Operational Energy and Environmental Sustainability with Reference to Green Buildings. J Pure Appl Sci Technol 2(1):11-22

69. European grid mix, http://people.exeter.ac.uk/TWDavies/energy conversion/Calculation\%20of\%20CO2\%20emissions\%20from\%20fuels.htm. Accessed 13 Sep 2016

70. Exeter, http://people.exeter.ac.uk/TWDavies/energy_conversion/ Calculation\%20of\%20CO2\%20emissions\%20from\%20fuels.htm Accessed 13 Sep 2016

71. Centrum voor Energiebesparing (2014) Stroometikettering in Nederland. CE, Delft, report

72. EEA emission factors, http://www.eea.europa.eu/data-and-maps/indicators/ energy-efficiency-and-specific-co2-emissions/energy-efficiency-and-specificco2-5. Accessed 13 Sep 2016

73. EPA, https://www.epa.gov/sites/production/files/2015-07/documents/ emission-factors_2014.pdf. Accessed 13 Sep 2016

\section{Submit your manuscript to a SpringerOpen ${ }^{\circ}$ journal and benefit from:}

- Convenient online submission

- Rigorous peer review

- Immediate publication on acceptance

- Open access: articles freely available online

- High visibility within the field

- Retaining the copyright to your article 